\title{
Contributions \\ NEURAL ENCODING OF CONSONANT-VOWEL TRANSITION IN CHILDREN WITH CENTRAL AUDITORY PROCESSING DISORDER
} A Study design/planning B Data collection/entry C Data analysis/statistics Data analysis/statistics D Data interpretation E Preparation of manuscrip F Literature analysis/search G Funds collection

\author{
Prawin Kumar ${ }^{1 A, C-D, F}$, Himanshu Kumar Sanju ${ }^{2 B-C, E-F}$, Niraj Kumar Singh ${ }^{1 A, C-D, F}$ \\ ${ }^{1}$ Department of Audiology, All India Institute of Speech and Hearing, Mysuru, Karnataka, \\ India \\ ${ }^{2}$ Department of ENT, Audiology and Speech Language Pathology, Sri Jagdamba \\ Education and Research Institute, Sri Ganganagar, Rajasthan, India
}

Corresponding author: Himanshu Kumar Sanju, Assistant Professor of Audiology, Department of ENT, Audiology and Speech Language Pathology, Sri Jagdamba Education and Research Institute, Sri Ganganagar, Rajasthan, India; email: himanshusanjuaslp@gmail.com

\begin{abstract}
Background: Previous studies have used the acoustic change complex (ACC) as a tool to investigate the perception of acoustic changes in an ongoing signal in various populations. However, there is no study that has explored the usefulness of ACC to objectively study the neural representation of CV transition in children with CAPD. The present study aims to investigate the utility of ACC as an objective tool to study neural representation of a CV transition in children with CAPD.

Material and methods: There were 40 children aged 8 to 14 years in this study. They were divided into 2 groups of 20 children each based on the outcomes of audiological tests: a clinical group (CAPD) and a comparison group. A diagnosis of CAPD was made for 20 children after completion of a two-stage evaluation process (screening and diagnosis). The ACC was acquired using Neuro Scan Syn (v. 4.4) for the naturally produced CV stimulus /sa/ which had a total duration of $380 \mathrm{~ms}$.

Results: A Mann-Whitney U-test revealed significantly delayed latency of $\mathrm{N1}^{\prime}$ and $\mathrm{P} 2$ ' in children with CAPD compared to healthy children. However, there was no significant difference in peak-to-peak amplitude of N1'-P2' between children with CAPD and normal children.

Conclusions: The prolonged latencies of ACC indicated poor encoding of the CV transition in children with CAPD. It is suggested that poor temporal processing of $\mathrm{CV}$ transitions in these children might be the reason for poor speech perception in the CAPD population.
\end{abstract}

Key words: CAPD • temporal processing • acoustic change complex (ACC)

\section{KODOWANIE NEURONALNE PRZEJŚCIA SPÓŁGŁOSKA-SAMOGŁOSKA U DZIECI Z CENTRALNYMI ZABURZENIAMI PRZETWARZANIA SŁUCHOWEGO}

\section{Streszczenie}

Wstęp: Wcześniejsze badania wykorzystywały kompleks zmiany akustycznej (ACC) jako narzędzie do badania percepcji zmian akustycznych w sygnale w różnych populacjach. Jednak nie ma żadnego badania, które sprawdzałoby przydatność ACC do obiektywnego badania neuronowej reprezentacji przejścia spółgłoska-samogłoska (CV) u dzieci z centralnymi zaburzeniami słuchu (CAPD). Niniejsze badanie ma na celu sprawdzenie użyteczności ACC jako obiektywnego narzędzia do badania neuronalnej reprezentacji przejścia CV u dzieci z CAPD.

Materiał i metody: W badaniu wzięło udział 40 dzieci w wieku od 8 do 14 lat. Na podstawie wyników badań audiologicznych podzielono je na 2 grupy po 20 dzieci: grupę kliniczną (CAPD) i grupę porównawczą. CAPD zdiagnozowano u 20 dzieci po zakończeniu dwuetapowego procesu oceny (badanie przesiewowe i diagnostyka). ACC uzyskano za pomocą Neuro Scan Syn (wersja 4.4) dla naturalnie wytwarzanego bodźca CV /sa/, który miał łączny czas trwania $380 \mathrm{~ms}$.

Wyniki: Test Manna-Whitneya-Wilcoxona ujawnił istotnie opóźnione latencje N1' i P2' u dzieci z CAPD w porównaniu ze zdrowymi dziećmi. Nie było jednak istotnej różnicy w amplitudzie pomiędzy maksimami fal N1' - P2' między dziećmi z CAPD a dziećmi zdrowymi.

Wnioski: Przedłużające się latencje ACC wskazywały na słabe kodowanie przejścia CV u dzieci z CAPD. Sugeruje się, że słabe przetwarzanie czasowe zmian CV u tych dzieci może być przyczyną złej percepcji mowy w populacji CAPD.

Słowa kluczowe: CAPD • przetwarzanie czasowe • kompleks zmian akustycznych (ACC)

\section{Introduction}

The acoustic change complex (ACC) is an effective tool to investigate neural representation of consonant-vowel transitions [1]. ACC shows discrimination at the level of the auditory cortex and provides a view into the brain's capacity to process the acoustic complexity of speech [2-4]. As the waveform reflects the acoustic change in a stimulus, the response was termed ACC by Martin and Boothroyd (1999) [5]. Although it is a cortical potential, ACC has been found to be useful in demonstrating the capacity of peripheral mechanisms to discriminate between two stimuli or identify a change in the same stimulus. One of the major advantage of ACC over other potentials is that it 
elicits responses with larger amplitudes and better signalto-noise ratios, thus requiring fewer stimulus presentations and less time for recording [5]. In addition, the ACC can be evoked reliably in individual participants and has good test-retest reliability. The stability of the ACC, and the ease with which it can be recorded, gives ACC the potential for investigating neural processing of speech.

During auditory perception of speech, the central auditory processing system has to process complex acoustic stimuli in real time. For speech and language development, good processing of complex acoustic stimuli is important [6]. Temporal processing ability, in particular, has a major role in speech perception. In some disorders, poor temporal processing skill results in impaired speech perception [7]. In $2014 \mathrm{He}$ et al. [8] showed a good correlation between ACC thresholds for electrode discrimination and PBK word scores. Previous studies have used ACC as a tool to investigate the perception of acoustic changes in ongoing signals in various populations [2,9-13]. Earlier literature has reported poor processing of speech in individuals with auditory processing disorder $[14,15]$. Previous reports have noted deficits in speech perception in children who have poor reading skill [16]. Poor speech perception in these individuals may be due to poor encoding of $\mathrm{CV}$ (or $\mathrm{VC}$ ) transitions leading to poor temporal processing. Neural representation of CV transitions has been studied in various populations $[2,4,11,13]$. However, to the best of our knowledge there has been no study that has explored the usefulness of ACC as an objective tool to study the neural representation of CV transitions in children with CAPD. So the present study aims to fill that gap by using ACC to investigate the neural representation of a CV transition in such children. The present study compares ACC measures in healthy children and in children with CAPD.

\section{Method}

After the approval from the ethical committee of All India Institute of Speech and Hearing, Mysore, India, 40 children aged 8 to 14 years from an English medium school were recruited for this study. Informed written consent was taken from the parents of all the children. They were divided into 2 groups of 20 children each (i.e. a clinical group and a comparison group) based on the outcomes of audiological tests. Group I (Comparison/control group) consisted of 20 healthy children (mean age 10.3 years) with normal hearing and without APD. To rule out APD in group I, screening for auditory processing disorder using SCAP and STAP were administered. Group II (clinical group) consisted of 20 children with CAPD (mean age 10.5 years) having normal hearing. Diagnosis of CAPD was made after completion of a two-stage evaluation process (screening and diagnosis). To diagnose the children as having CAPD, SPIN (speech in noise), dichotic CV test, and a gap detection threshold test were used. The children who failed in all these tests were included in the present study.

\section{Instrumentation}

A well calibrated dual-channel diagnostic audiometer, MAICO MA-52, with TDH-50 headphones was used to assess air conduction thresholds at octave frequencies between 0.25 and $8 \mathrm{kHz}$. Bone conduction thresholds were estimated at octave frequencies between 0.25 and $4 \mathrm{kHz}$ using a Radioear B-71 bone vibrator coupled to the same audiometer. Speech audiometry was done to estimate speech recognition scores and speech identification scores. A calibrated middle ear analyzer (GSI-Tympstar) was used to obtain tympanograms and acoustic reflex thresholds. A probe tone of $226 \mathrm{~Hz}$ was used and ipsilateral and contralateral acoustic reflex thresholds were measured at octave frequencies between 0.5 and $4 \mathrm{kHz}$. To screen for risk of (C)APD, STAP was carried out with a CD played on a personal laptop (Intel Core i3) with a set of calibrated supra-aural headphones (Pulse 5). The ACC was recorded using a NeuroScan SynAmps ${ }^{2}$ data acquisition system for recording the EEG and a NeuroScan STIM² (v.4.4) for stimulus presentation.

\section{Test environment}

Audiological evaluation and administration of psychophysical as well as electrophysiological tests were carried out in a sound-treated room with ambient noise levels within permissible limits (ANSI 1991). Audiometric testing was done in a double room. However, psychophysical and electrophysiological tests were done in a single room situation.

\section{Stimulus preparation}

ACC was recorded for the naturally produced CV stimulus /sa/ which has a total duration of $380 \mathrm{~ms}$, which consists of a consonant (duration $150 \mathrm{~ms}$ ) and vowel $(230 \mathrm{~ms})$. The consonant /s/ is an unvoiced alveolar fricative and is joined to a low back vowel /a/. A total of $3 \mathrm{CV}$ stimuli were recorded using Adobe Audition (v.3) from three adults who were recorded using a microphone (AUD-101XLR, Ahuja Radios, New Delhi, India) placed $10 \mathrm{~cm}$ from the lips. The signal was of 32 bit depth and was sampled at $48 \mathrm{kHz}$. All the recorded stimuli were normalized. Praat software (v. 5.1.29, University of Amsterdam, The Netherlands) was used to analyze acoustic waveforms and spectrograms of the stimuli. Ten individuals with normal hearing were used to rate the naturalness of the recorded CV syllables. Figure 1 shows the waveform of the /sa/ stimulus. Figure 2 presents a spectrogram of / sa/ which shows a fundamental frequency of $133 \mathrm{~Hz}$.

\section{Procedure}

All participants underwent air-conduction and boneconduction pure-tone audiometry to verify normal hearing thresholds. Speech recognition threshold (SRT) was assessed using the standardized paired word list in Kannada and it showed fair agreement with the pure-tone average. Speech identification scores were obtained at $40 \mathrm{~dB} \mathrm{HL}$ above the SRT using the standardized phonemically balanced (PB) word lists in Kannada. Tympanometry and reflexometry were done for all participants to check middle ear functioning. This involved the use of a probe tone of $226 \mathrm{~Hz}$ at $85 \mathrm{~dB}$ SPL and a sweep in the air pressure in the external ear canal from +200 to $-400 \mathrm{daPa}$. Acoustic reflex thresholds were measured for octave frequencies between $500 \mathrm{~Hz}$ and $4000 \mathrm{~Hz}$ both ipsilaterally and contralaterally. DPOAEs were measured using DP Echoport ILO (v. 6). A standard DPOAE probe tip was positioned 


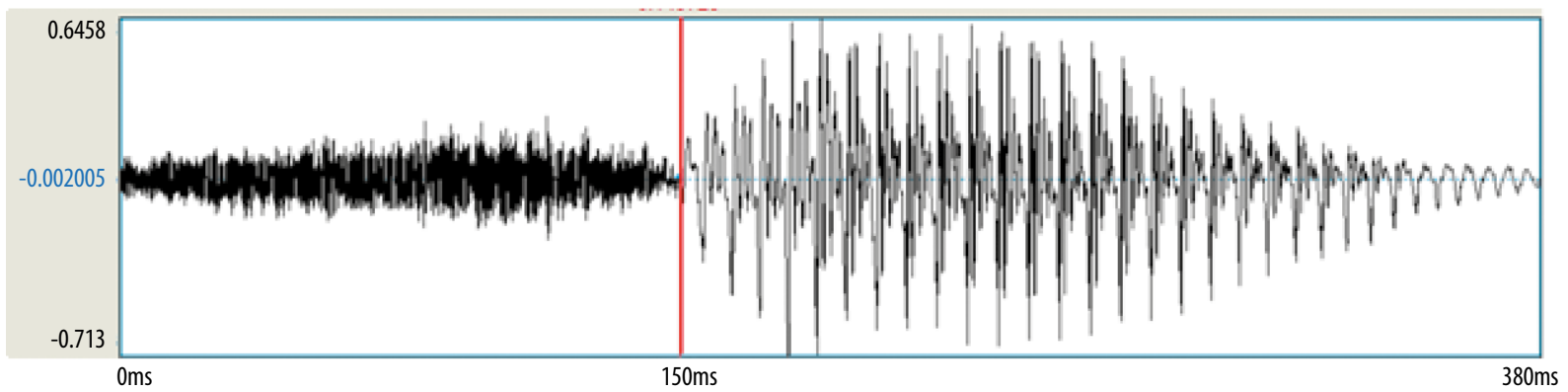

Figure 1. Waveform of /sa/ stimulus

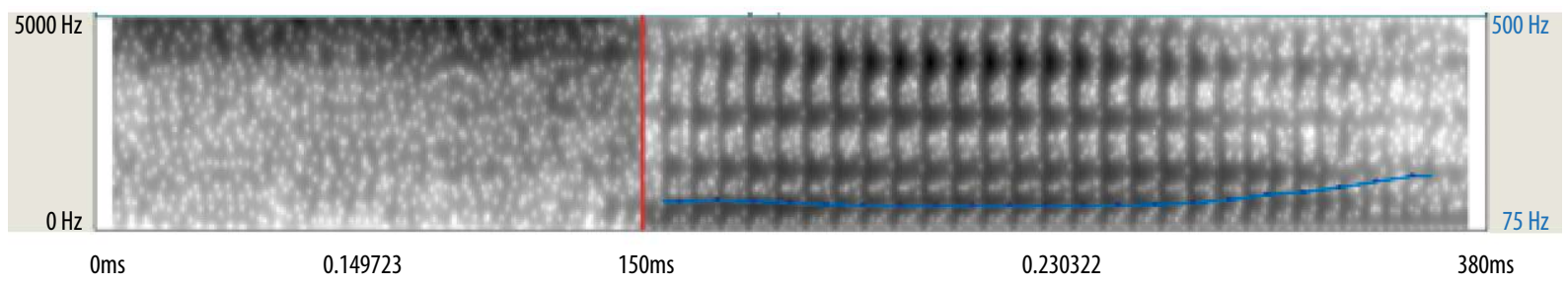

Figure 2. Spectrogram of the same /sa/ stimulus as in Figure 1

in the participant's ear canal and the ratio $\mathrm{f} 2 / \mathrm{f} 1$ was kept constant at 1.22; stimulus intensity was fixed at 65 and $55 \mathrm{~dB}$ SPL for $\mathrm{f} 2$ and $\mathrm{f} 1$ respectively. The level of the 2f1-f2 second order distortion product) DPOAE was plotted as a function of frequency from 1 to $6 \mathrm{kHz}$. DPOAEs were considered present when the signal-to-noise ratio was $\geq 3 \mathrm{~dB}$ [17]. To rule out retrocochlear pathology, auditory brainstem responses (site of lesion) were done on all children participating in the study.

A dichotic CV test was used for assessment of binaural integration. Two different consonant-vowel (CV) syllables were presented to the two ears with a $0 \mathrm{~ms}$ lag between them and the child's task was to identify the CV syllables irrespective of the ear [18]. GDT was assessed using a maximum likelihood procedure (MLP) toolbox implemented in MATLAB. Gap detection threshold was calculated using $750 \mathrm{~ms}$ of Gaussian noise with a gap in the center. Here, gap duration was varied according to subject performance using MLP. The noise had $0.5 \mathrm{~ms}$ cosine ramps at the start and end of the gap. A three-alternative forced-choice method was used in which the reference stimulus was always $750 \mathrm{~ms}$ white noise (without gap), whereas the variable stimulus consisted of a gap. The child's task was to identify the noise token that had the gap. SPIN was done for all the subjects at $0 \mathrm{~dB}$ SNR.

\section{Recording of ACC}

The ACC was acquired using the NeuroScan Syn$\mathrm{Amps}^{2}$ data acquisition system for recording the EEG and a NeuroScan STIM $^{2}$ (v. 4.4) for stimulus presentation. The participants were comfortably seated in a reclining chair and were instructed to minimise head and body movements. Disc type $\mathrm{Ag}-\mathrm{AgCl}$ electrodes were placed at the recording sites using 10-20 conduction paste. The non-inverting electrode was placed at Cz. The inverting electrode was positioned on the ipsilateral mastoid and the ground electrode was positioned on the contralateral mastoid. ACC was recorded for the naturally produced stimulus token /sa/ (CV) of total duration $380 \mathrm{~ms}$, which included a consonant duration of $150 \mathrm{~ms}$ and vowel duration of $230 \mathrm{~ms}$. Intensity calibration was done for the CV stimulus and was kept at $80 \mathrm{~dB}$ SPL. Stimuli were presented to the participants monaurally via ER-3A insert earphones. The raw EEG output of the electrodes was recorded in the acquired module of the Scan 4.5 suite interfaced by a SynAmps ${ }^{2}$ pre-amplifier. The online EEG was recorded at an analog-to-digital sampling rate of $1 \mathrm{kHz}$. The EEG was band-pass filtered online from 0.1 to $100 \mathrm{~Hz}$ ( $12 \mathrm{~dB} /$ oct roll-off) and all channels were amplified by a factor of 2010. For each recording, the stimuli were presented 150 times. To aid cooperation, while recording the ACC the children watched a muted movie played through a battery-operated laptop at a distance of $2 \mathrm{~m}$. Breaks were provided whenever requested.

The recorded EEG was analyzed offline. Ocular artifact reduction was performed using linear regression [19] implemented in the Compumedics Neuroscan instrument. The continuous EEG was epoched with a time window consisting of a $100 \mathrm{~ms}$ pre-stimulus period and $1000 \mathrm{~ms}$ poststimulus time. Epoched responses were baseline corrected and off-line band-pass filtered from 0.1 to $30 \mathrm{~Hz}(12 \mathrm{~dB} /$ oct roll-off, zero phase shift FIR filter). Epochs with signals greater than $\pm 100 \mu \mathrm{V}$ were excluded from averaging. All evoked waveforms were analyzed from the electrode site $\mathrm{Cz}$. The interstimulus interval was $1 \mathrm{~s}$. All responses were then averaged to obtain the final ACC waveform. N1' and P2' are the negative and positive peaks of ACC respectively. Waveforms were evaluated by two experienced audiologists for the presence of ACC and excellent agreement between them was found (Kappa analysis, $\kappa=0.95$ ).

\section{Results}

IBM SPSS 20 was used for data analysis. Descriptive statistics was done to find the mean and standard deviation of 
Table 1. Mean and standard deviation (SD) of different measures of ACC in normal children and children with CAPD

\begin{tabular}{|c|c|c|c|c|c|c|}
\hline \multirow[t]{2}{*}{ Group } & \multicolumn{2}{|c|}{$\begin{array}{l}\text { N1' latency } \\
\text { (ms) }\end{array}$} & \multicolumn{2}{|c|}{$\begin{array}{l}\text { P2' latency } \\
\text { (ms) }\end{array}$} & \multicolumn{2}{|c|}{$\begin{array}{l}\text { N1'- P2' (peak-to-peak } \\
\text { amplitude in } \mu \mathrm{V})\end{array}$} \\
\hline & mean & SD & mean & SD & Mean & SD \\
\hline Normal & 277.2 & 15.7 & 337.6 & 18.3 & 1.82 & 0.91 \\
\hline CAPD & 374.7 & 32.6 & 438.1 & 38.1 & 1.71 & 0.86 \\
\hline
\end{tabular}

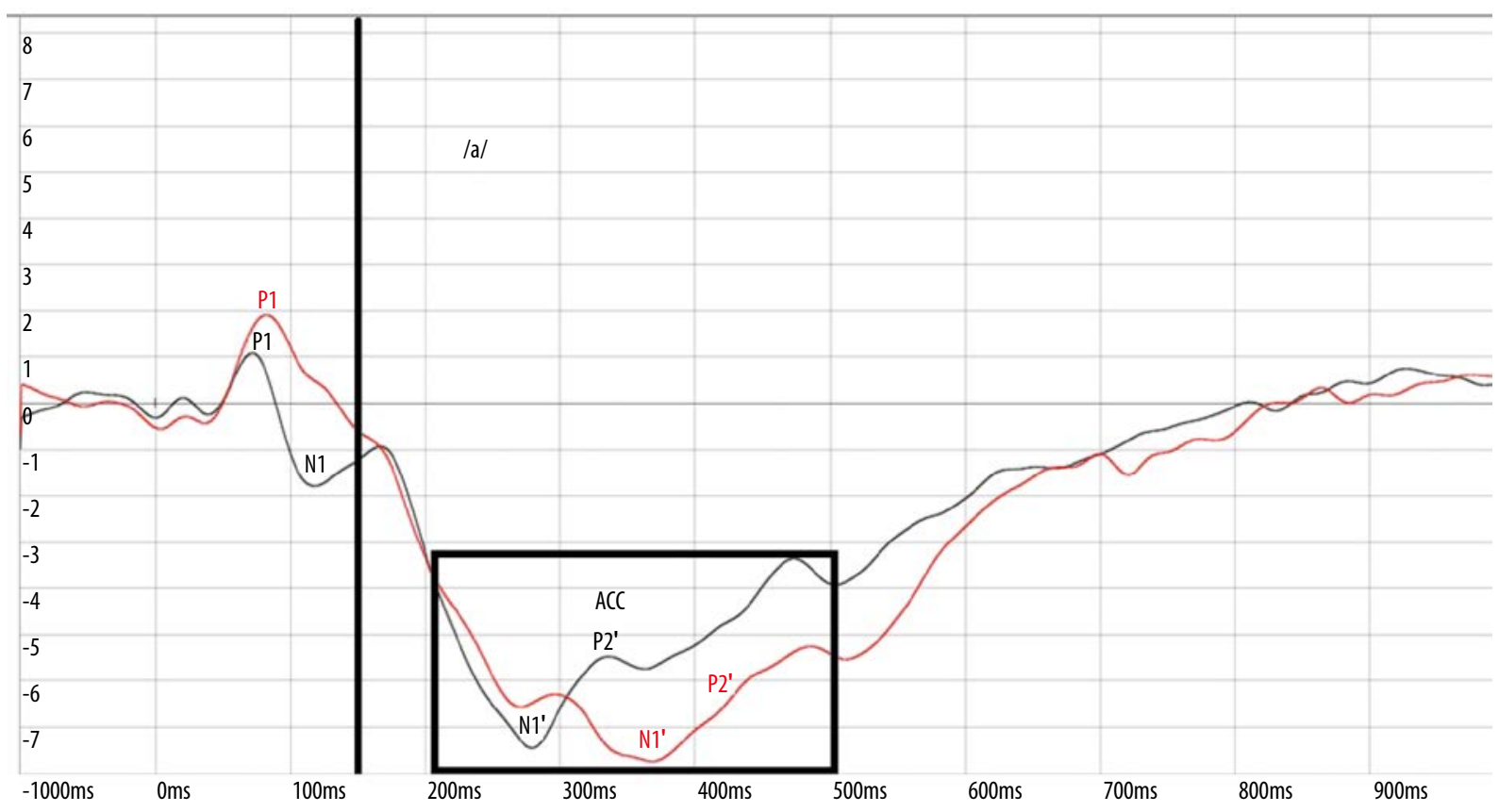

Figure 3. Grand mean average waveform of acoustic change complex for normal children (black) and children with CAPD (red)

latency ( $\mathrm{N1}^{\prime}$ and $\mathrm{P} 2$ ') and peak-to-peak amplitude (N1'P2') of ACC for both groups. Results showed prolonged latencies (poorer) N1 and P2 in children with CAPD compared to healthy children. Descriptive statistics also revealed smaller peak-to-peak amplitude (poorer) for $\mathrm{N} 1-\mathrm{P} 2$ in children with CAPD compared to normal children. Means and standard deviations of all measures of ACC are given in Table 1 .

In Figure 3, the black waveform is the grand mean average ACC waveform of normal children, whereas the red waveform is the grand mean average waveform of children with CAPD.

Shapiro-Wilk tests of normality were used to check the distribution of the collected data. The tests showed a non-normal distribution of the collected data $(p<0.05)$. Different measures of ACC (latencies and peak-to-peak amplitudes) were compared to assess the significance of the difference between healthy children and children with CAPD. Mann-Whitney U-tests revealed significantly delayed latency of $\mathrm{N}^{\prime}(U=14.50, Z=-5.02, p<0.001)$ and $\mathrm{P} 2 '$ $(U=9, Z=-5.16, p<0.001)$ in children with CAPD compared to healthy children. However, U-tests revealed no significant difference in peak-to-peak amplitude of $\mathrm{N}^{\prime}{ }^{\prime}-$ P2' $(U=179, Z=-0.02, p>0.05)$ between children with CAPD and normal children.

\section{Discussion}

Temporal resolution is the ability to process acoustic signals over time. There was a dearth of literature regarding investigation of $\mathrm{CV}$ transition using ACC in individuals with CAPD. Prolonged latencies of ACC indicated poor encoding of CV transition in childrenwith CAPD, which shows poor temporal processing of $\mathrm{CV}$ transition in these children. These changes in waveform morphology in children with CAPD revealed poor neural synchrony and weak neural connections associated with poor encoding of CV transition. This could be the one reason of poor speech perception in these individuals.

The outcome of the present study showed objective quantification of $\mathrm{CV}$ transition in children with auditory processing disorders. The finding of current study is in consonance with previous literature where researchers have quantified ability to detect CV transition through electrophysiological test in various populations [2,9-13]. Ostroff et al. [9] in 1998 obtained auditory cortical evoked potentials N1 and P2 with the syllable /sei/, sibilant/s/, and vowel /ei/ in normal hearing adults. They found that the response to /ei/ within the complete syllable mirrors changes of cortical activation due to spectral changes at the transition from consonant to vowel. They concluded that that the auditory cortical evoked potential to complex and time-varying speech 
waveforms can show the attribute of the essential acoustic patterns. They also indicated that such potential may have great value in the assessment of speech perception ability. Friesen and Tremblay [10] in 2006 also reported clinical implications of encoding of CV transition in assessment of speech perception ability in children with cochlear implant. Similarly, Martin in 2007 [12] also demonstrated implication of ACC as an objective tool to assess behavioral measures. Martinez et al. [2] in 2013 investigated ACC with speech stimuli demonstrating vowel height $/ \mathrm{u} /-/ \mathrm{a} /$ and vowel place $/ \mathrm{u} /-/ \mathrm{i} /$ contrasts on three group of subjects (i.e. adults with normal hearing, children with normal hearing and children with mild to moderately severe sensorineural hearing loss). They concluded that ACC can be used magnificently to evaluate auditory resolution capacity in most young children.

The outcome of present study showed poor encoding of $\mathrm{CV}$ transition could be due to well established evidence of poor temporal processing ability in children with CAPD $[20,21]$. Poor encoding of the spectrotemporal envelope at the level of higher auditory cortical pathway could be the reason of poor ACC in the present study [22]. Lotfi et al. (2020) investigated the spectrotemporal modulation
(STM) detection task in children with CAPD and showed higher STM detection threshold in children with CAPD compared to normal hearing peer [23].

Poor temporal resolution ability in children with CAPD can be the reason for poor STM detection threshold in these children. Poor coding of CV transition in children with CAPD could be due to reduction in the amount of contributing neurons, poor neural synchronization, poor myelination of neurons, immature cortical response, decrease in synaptic density as reported and well established by previous literature [24,25]. Further studies can be done where researcher can explore ACC with background speech spectrum shaped noise in clinical populations.

\section{Conclusion}

The results of the present study revealed poor encoding of a CV transition at the cortical level in children with CAPD. The findings of the present study suggest poor temporal processing ability in children with CAPD. Perhaps poor speech perception might be due to poor encoding of consonant-vowel transitions in these children.

\section{References}

1. Tremblay KL, Kalstein L, Billings CJ, Souza PE. The neural representation of consonant-vowel transitions in adults who wear hearing AIDS. Trends Amplif, 2006;10(3):155-62.

2. Martinez AS, Eisenberg LS, Boothroyd A. The Acoustic Change Complex in young children with hearing loss: a preliminary study. Semin Hear, 2013; 34:278-287.

3. Shetty HN, Puttabasappa M. Effect of stimuli, transducers and gender on acoustic change complex. Audiol Res, 2012; 2:e14.

4. Chen KH, Small SA. Elicitation of the acoustic change complex to long-duration speech stimuli in four-month-old infants. Int J Otolaryngol, 2015; 2015:562030.

5. Martin BA, Boothroyd A. Cortical, auditory, event-related potentials in response to periodic and aperiodic stimuli with the same spectral envelope. Ear Hear, 1999; 20:33-44.

6. Gallagher TM. Treatment research in speech, language and swallowing: lessons from child language disorders. Folia Phoniatr Logop, 1998;50(3):165-82.

7. Narne VK. Temporal processing and speech perception in noise by listeners with auditory neuropathy. PLOS One, 2013; 8:e55995.

8. He S, Grose JH, Teagle HF, Woodard J, Park LR, Hatch DR, Roush P, Buchman CA. Acoustically evoked auditory change complex in children with auditory neuropathy spectrum disorder: a potential objective tool for identifying cochlear implant candidates. Ear Hear, 2015; 36:289-301.

9. Ostroff JM, Martin BA, Boothroyd A. Cortical evoked response to acoustic change within a syllable. Ear Hear, 1998; 19:290-297.

10. Friesen LM, Tremblay KL. Acoustic change complexes recorded in adult cochlear implant listeners. Ear Hear, 2006; 27:678-685.

11. Tremblay KL, Billings CJ, Friesen LM, Souza PE. Neural representation of amplified speech sounds. Ear Hear, 2006; 27:93-103.

12. Martin BA. Can the acoustic change complex be recorded in an individual with a cochlear implant? Separating neural responses from cochlear implant artifact. J Am Acad Audiol, 2007;18(2):126-40.

13. Small SA, Werker JF. Does the ACC have potential as an index of early speech discrimination ability? A preliminary study in 4-month-old infants with normal hearing. Ear Hear, 2012; 33:e59-69.
14. Pichora-fuller MK, Souza PE. Effects of aging on auditory processing of speech. Int J Audiol, 2003;42 Suppl 2:2S11-6.

15. Lagacé J, Jutras B, Gagné JP. Auditory processing disorder and speech perception problems in noise: finding the underlying origin. Am J Audiol, 2010;19(1):17-25.

16. Mody M, Studdert-kennedy M, Brady S. Speech perception deficits in poor readers: auditory processing or phonological coding? J Exp Child Psychol, 1997;64(2):199-231.

17. Moulin A, Collet L, Duclaux R. Contralateral auditory stimulation alters acoustic distortion products in humans. Hear Res, 1993;65(1-2):193-210.

18. Gowri K. Dichotic CV test: revised normative data on children. (Unpublished independent project) University of Mysore, Mysore, 2001.

19. Semlitsch HV, Anderer P, Schuster P, Presslich O. A solution for reliable and valid reduction of ocular artifacts, applied to the P300 ERP. Psychophysiol, 1986;23(6):695-703.

20. Jerger J, Musiek F. Report of the Consensus Conference on the Diagnosis of Auditory Processing Disorders in School-Aged Children. J Am Acad Audiol, 2000;11(9):467-74.

21. Dawes P, Bishop DV. Maturation of visual and auditory temporal processing in school-aged children. J Speech Lang Hear Res, 2008;51(4):1002-15.

22. Ankmnal-Veeranna S, Allan C, Macpherson E, Allen P. Spectral ripple discrimination in children with auditory processing disorder. Int J Audiol, 2019;58(11):733-737.

23. Lotfi Y, Moossavi A, Afshari PJ, Bakhshi E, Sadjedi H. Spectrotemporal modulation detection and its relation to speech perception in children with auditory processing disorder. Int J Pediatr Otorhinolaryngol, 2020;131(1):109860.

24. Ceponiene R, Rinne T, Näätänen R. Maturation of cortical sound processing as indexed by event-related potentials. Clin Neurophysiol, 2002;113(6):870-82.

25. Koravand A, Jutras B, Lassonde M. Abnormalities in cortical auditory responses in children with central auditory processing disorder. Neuroscience, 2017;346:135-148. 